Terakreditasi: SK No.: 60/E/KPT/2016

Website : http://ejournal.undip.ac.id/index.php/reaktor/

Reaktor, Vol. 17 No. 2, Juni Tahun 2017, Hal. 89-95

\title{
Influence of Solution Initial pH on Biofilm Formation and Corrosion of Carbon Steel by Serratia marcescens
}

\section{Ardiyan Harimawan*), Hary Devianto, Ignatius Chandra Kurniawan, dan Josephine Christine Utomo}

Department of Chemical Engineering, Faculty of Industrial Technology, Institut Teknologi Bandung Jl. Ganesha 10 Bandung, Telp./Fax. (022) 2500989/(022) 2501438

${ }^{*}$ Corresponding author: ardiyan@che.itb.ac.id

\begin{abstract}
The growth of Serratia marcescens depends on its metabolism, which is influenced by environmental factors, such as $\mathrm{pH}$ and temperature. The metabolic activity of Serratia marcescens may influence the corrosion of carbon steel by forming a biofilm on the metal surface. This research is focused on determining the effect of $\mathrm{pH}$ on carbon steel corrosion caused by Serratia marcescens. The medium used as immersion solution was a mixture of synthetic seawater and Luria-Bertani medium with a volume ratio of 4:1. The carbon steel coupons with a size of $1 \mathrm{~cm} \times 1 \mathrm{~cm}$ were immersed in the solution with initial pH of 5, 7, and 9. The analyses of biofilm were conducted by total plate count (TPC), scanning electron microscopy (SEM) and Fourier transform infrared spectroscopy (FTIR). Biofilm was detected evenly on the metal surface and decreased with an increase in incubation $\mathrm{pH}$. The biofilm consists of some functional groups, such as alcohol, alkane, amine, nitro, sulphate, carboxylic acid, and polysulfide. The analyses of the corrosion were conducted by gravimetric and X-ray diffraction (XRD). The $\mathrm{pHs}$ of 5 and 9 were found to give an increase in the corrosion rate. The average corrosion rate at $\mathrm{pH}$ variations of 5, 7, and 9 were $2.5309 \mathrm{~g} / \mathrm{m}^{2}$.day; $2.2844 \mathrm{~g} / \mathrm{m}^{2}$.day; and $2.9756 \mathrm{~g} / \mathrm{m}^{2}$.day, respectively. Nevertheless, the corrosion products were not detected by XRD analysis.
\end{abstract}

Keywords: biocorrosion; carbon steel; $p H$; seawater; Serratia marcescens

\section{Abstrak}

PENGARUH PH AWAL LARUTAN PADA PEMBENTUKAN BIOFILM DAN KOROSI BAJA KARBON OLEH Serratia marcescens. Laju pertumbuhan Serratia marcescens bergantung pada aktivitas metabolise mikroba, yang akan sangat dipengaruhi oleh faktor lingkungan, seperti $\mathrm{pH}$ dan temperatur. Aktivitas metabolisme Serratia marcescens dapat memengaruhi korosi pada baja karbon dengan membentuk lapisan biofilm pada permukaan logam. Penelitian ini bertujuan untuk menentukan efek $\mathrm{pH}$ pada korosi baja karbon yang disebabkan oleh Serratia marcescens. Media yang digunakan sebagai larutan perendam adalah campuran air laut sintetis dan media Luria-Bertani dengan perbandingan volume sebesar 4:1. Kupon baja karbon dengan ukuran $1 \mathrm{~cm}$ x $1 \mathrm{~cm}$ direndam dalam larutan dengan pH awal 5, 7, dan 9. Analisis lapisan biofilm dilakukan dengan total plate count (TPC), scanning electron microscopy (SEM) dan Fourier transform infrared spectroscopy (FTIR). Lapisan biofilm tumbuh secara merata pada permukaan logam dan berkurang seiring dengan peningkatan $\mathrm{pH}$ inkubasi. Lapisan biofilm mengandung berbagai gugus fungsional, seperti alkohol, alkana, amin, nitro, sulfat, asam karboksilat, dan polisulfida. Analisa korosi dilakukan dengan gravimetri dan $X$-ray diffraction (XRD). Penggunaan pH 5 dan 9 memberikan peningkatan terhadap laju korosi. Laju korosi rata-rata pada $\mathrm{pH}$ 5, 7, dan 9 ditentukan sebesar 2,5309 $\mathrm{g} / \mathrm{m}^{2}$.day; 2,2844 g/m².day; and 2,9756 $\mathrm{g} / \mathrm{m}^{2}$.day. Namun, produk korosi tidak terdeksi oleh analisis XRD.

Kata kunci: biokorosi; baja karbon; pH; air laut; Serratia marcescens 
How to Cite This Article: Harimawan, A., Devianto, H., Kurniawan, I.C., dan Utomo, J.C., (2017), Influence of Solution Initial pH on Biofilm Formation and Corrosion of Carbon Steel by Serratia marcescens, Reaktor, 17(2), 8996, http://dx.doi.org/10.14710/reaktor.17.2.89-96

\section{INTRODUCTION}

Biocorrosion is one type of corrosion which is influenced by microbial activities directly or indirectly. The microorganisms can lead to biocorrosion by adhering on the metal surface and forming a biofilm (Javaherdashti, 2008). The microorganisms can produce extracellular products, like a polysaccharide matrix, when forming the biofilm (Costerton et al., 1995). These products can influence the electrochemical reactions between the biofilm and metal, which leads to metal corrosion. Biocorrosion is estimated to cause around $34 \%$ of the equipment damage in oil companies (Jack et al., 1992), $50 \%$ of the pipeline corrosion (Flemming, 1996), and 20\% of the total corrosion on metal (Brennenstuhl and Doherty, 1990). One of the biocorrosion cases, in industry, is commonly found in heat exchangers. Biocorrosion can cause leakage and cost losses around 55 million dollars over eight years (Brennenstuhl and Doherty, 1990).

Biocorrosion might be caused by various microorganism types, that may lead to different corrosion mechanisms and reaction kinetics. Sulphatereducing bacteria (SRB), one of the microorganism types, has been known to cause biocorrosion (Muthukumar et al., 2006). Apart from the microorganism types, various environmental conditions may also result in different effects on biocorrosion. The influence of environmental conditions on SRB corrosion has been studied, such as the influence of inhibitor (Muthukumar et al., 2006), the presence of heavy metals (Fang et al., 2002), sulfide ions (Yuan et al., 2013), nitrate ions (Pillay et al., 2014), carbon source (Xu et al., 2014), pH (Ismail et al., 2014), and temperature (Ismail et al., 2014). However, the influence of environmental conditions on biocorrosion caused by Serratia marcescens has not been extensively studied. Thus, this study investigates the effect of initial $\mathrm{pH}$ solution on the biofilm formation and corrosion of carbon steel by Serratia marcescens.

\section{MATERIAL AND METHODS}

The microorganism used in this research was Serratia marcescens ATCC 27117 and the specimens used were metal plates of carbon steel ST 37 . The incubation medium or immersion solution used were a mixture of $80 \%-\mathrm{v} / \mathrm{v}$ seawater and $20 \%-\mathrm{v} / \mathrm{v}$ LuriaBertani broth. The composition of artificial seawater and Luria-Bertani broth were presented in Table 1 (Xiaoxia, 2007) and Table 2 (Hejazi and Falkiner, 1997), respectively.

There are some parameters that was considered in this study, such as the number of microorganism colonies on the metal surface; the compositions and morphology of biofilm; the corrosion rate; and the corrosion products. The specimens were immersed both in seawater with and without Serratia marcescens (as the control variable). This experiment consists of three fundamental steps: (1) the preparation, (2) the main experiment, and (3) the analysis.

Table 1. Composition of artificial seawater

\begin{tabular}{lc}
\hline Compound & Composition $(\mathrm{g} / \mathrm{L})$ \\
\hline $\mathrm{NaCl}_{2}$ & 23.476 \\
$\mathrm{Na}_{2} \mathrm{SO}_{4}$ & 3.917 \\
$\mathrm{NaHCO}_{3}$ & 0.192 \\
$\mathrm{KCl}$ & 0.664 \\
$\mathrm{H}_{3} \mathrm{BO}_{3}$ & 0.026 \\
$\mathrm{MgCl}_{2} .6 \mathrm{H}_{2} \mathrm{O}$ & 10.610 \\
$\mathrm{SrCl}_{2} .6 \mathrm{H}_{2} \mathrm{O}$ & 0.04 \\
$\mathrm{CaCl}_{2}$ & 1.109 \\
\hline
\end{tabular}

Table 2. Composition of Luria Bertani medium

\begin{tabular}{lc}
\hline Compound & Composition $(\mathrm{g} / \mathrm{L})$ \\
\hline Tryptone & 10 \\
$\mathrm{NaCl}$ & 10 \\
Yeast extract & 5 \\
\hline
\end{tabular}

The preparation consists of several steps: the inoculation of Serratia marcescens, the preparation of incubation solution, specimens, and reactors. The inoculation steps were done in order to increase the number of Serratia marcescens which will be cultured in the incubation medium. Serratia marcescens was inoculated to the incubation medium when entering the death phase. The growth of Serratia marcescens was obtained with the measurement of absorbance number, which was conducted by using UV-Vis spectrophotometer at $520 \mathrm{~nm}$.

The specimen preparation consists of several steps. First, the metal was cut into $1 \mathrm{~cm} \mathrm{x} 1 \mathrm{~cm}$ based on ASTM G31-72 and the incubation solution volume was $200 \mathrm{ml}$. The surface area used was $8 \mathrm{~cm}^{2}$ in total for four specimens per reactor. Based on ASTM G1-81, the specimen surface should be smoothed using abrasive paper grid from 240 to 1200 . The specimens and reactor design used in this experiment were shown in Figure 1 and Figure 2, respectively.

The main experiment includes the incubation of the specimens in the medium containing Serratia marcescens. The specimens were hanging in the reactor for 19 days. The reactor was incubated with initial $\mathrm{pH}$ solution of 5,7 , and 9 .

The analysis for biofilm formation and carbon steel corrosion were assessed by Total Plate Count (TPC) to count the number of colonies in biofilm; Scanning Electron Microscopy (SEM) to know the biofilm morphology; Fourier Transform Infrared Spectroscopy (FTIR) to detect the surface functional group of biofilm; gravimetric to measure the corrosion rate; and X-ray diffraction (XRD) to detect the corrosion products. The samples for TPC were taken at day 5, 12, 16, 22, and 23; gravimetric analysis were taken at day 7, 9, 14, 16, and 19; SEM at day 7 and 19; FTIR at day 10; and XRD at day 19. 


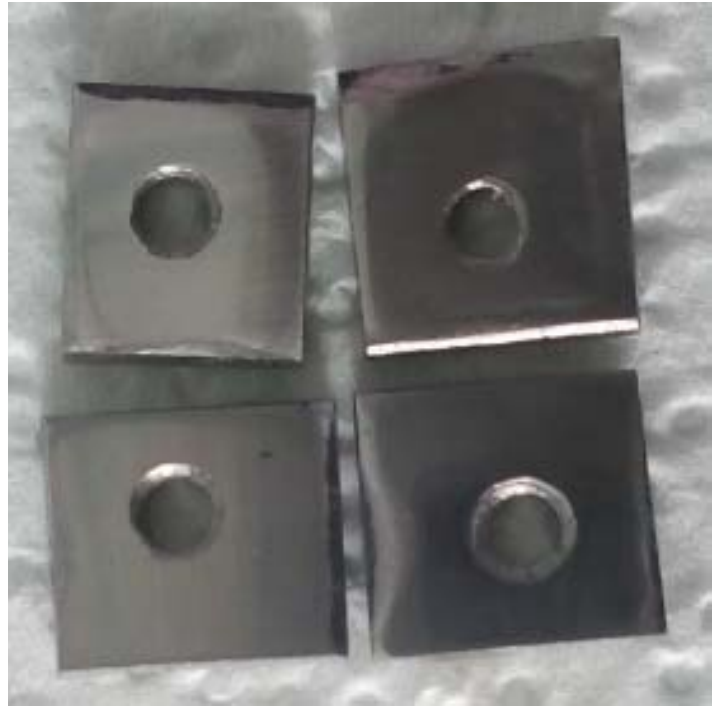

Figure 1. Carbon steel specimens

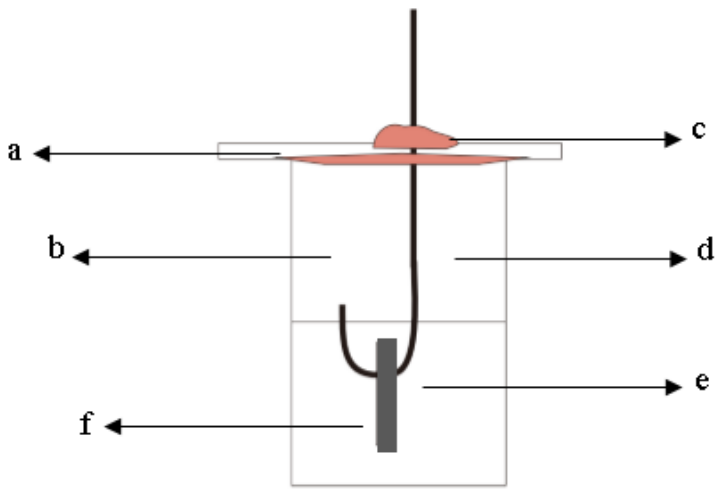

Figure 2. Reactor design: (a) cover, (b) body, (c) wax,

(d) hook, (e) specimens, and (f) medium

\section{RESULTS AND DISCUSSIONS}

Serratia marcescens is one of microorganisms which can be found in seawater. Before the main experiment, Serratia marcescens was adapted to the incubation medium, which contains seawater and Luria-Bertani broth mixture. The growth curves of Serratia marcescens were made in order to estimate the time when Serratia marcescens enters the death phase. The growth curves were developed in three variations of medium compositions $(80 \%, 90 \%$, and $100 \%$-v/v seawater). Figure 3 shows the growth curves of Serratia marcescens in those three variations. The curves indicate that the favorable medium compositions for Serratia marcescens growth is in the medium with $80 \%$-v/v seawater.

To compare the ability of Serratia marcescens to survive in the biofilm, the growth of Serratia marcescens in the biofilm and immersion solution has been analyzed. The growth of Serratia marcescens in the immersion solution was analyzed by spectrophotometer, while the growth in biofilm was analyzed by TPC. The comparison of Serratia marcescens growth in the biofilm and medium is presented in Figure 4.

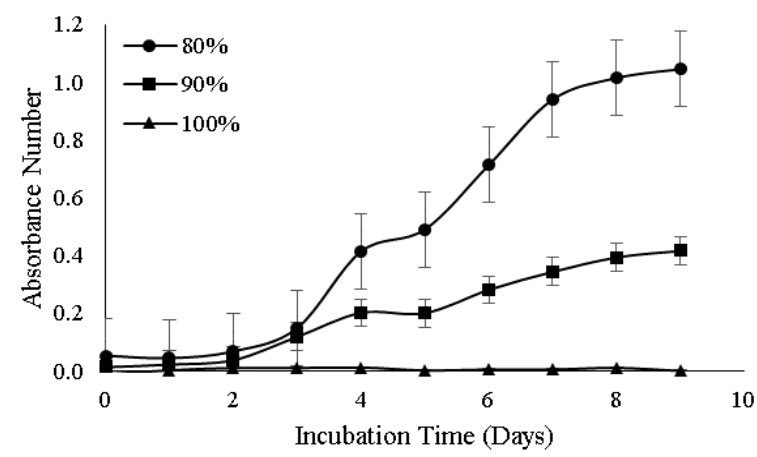

Figure 3. Growth curve of Serratia marcescens in the medium: 80,90 , and $100 \%$ seawater

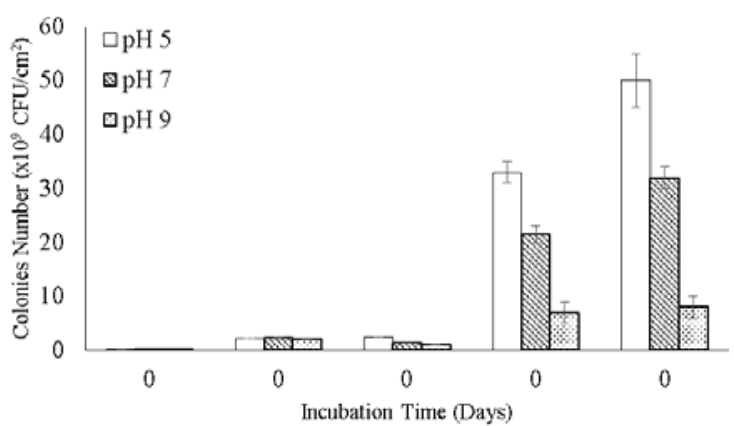

(a)

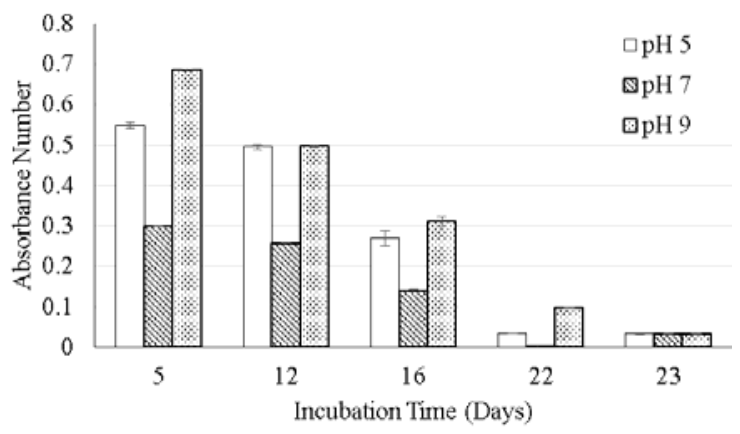

(b)

Figure 4. Comparison of Serratia marcescens growth in: (a) biofilm and (b) immersion solution

The growth of Serratia marcescens in biofilm showed positive trends along the incubation periods for all variations. In biofilm, the growth of Serratia marcescens increased rapidly at day 22. Serratia marcescens growth in solution showed a contradictory trend compared with that in biofilm. There were gradual decline of Serratia marcescens growth for all variations. This situation may occur due to the decrease in the concentration of nutrients, which contributes to the growth of Serratia marcescens in the solution, and so the declining growth of Serratia marcescens occured and made the biofilm grew on the metal surface. This can be seen by the increasing number of colonies in the biofilm.

Based on Figure 4b, Serratia marcescens growth was higher in the immersion solution with $\mathrm{pH} 5$ and 9. This may occur due to the addition of nutrients in the form of citric acid at $\mathrm{pH} 5$ and phosphate at $\mathrm{pH}$ 
9. Both nutrients were able to be metabolized by $S$. marcescens where citric acid can be metabolized via the citric acid metabolism cycle and phosphate is used as a source of metabolic energy in the form of ATP or NADP.

The biofilm morphology analyses on metal surface was performed using SEM with magnification of 2000x. The comparison was conducted between metal surface before incubation (Figure 5) and after incubation for day 7 and 19 (Figures 6 and 7).

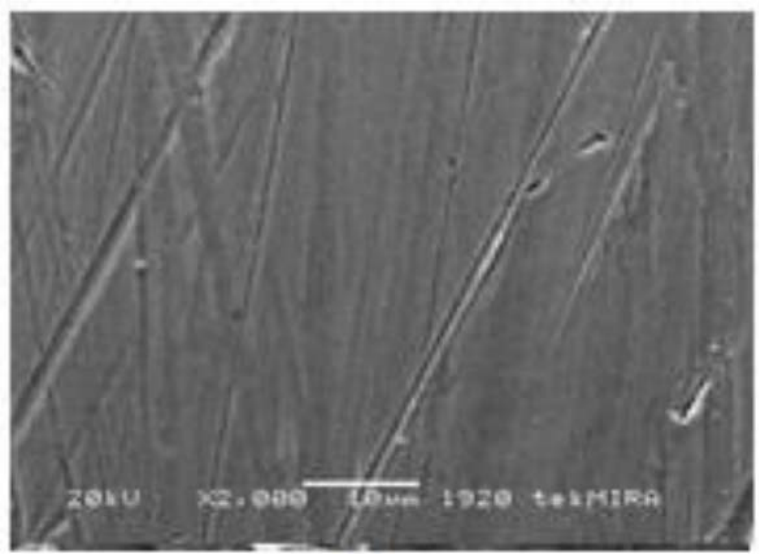

Figure 5. Morphology of metal surface before incubation

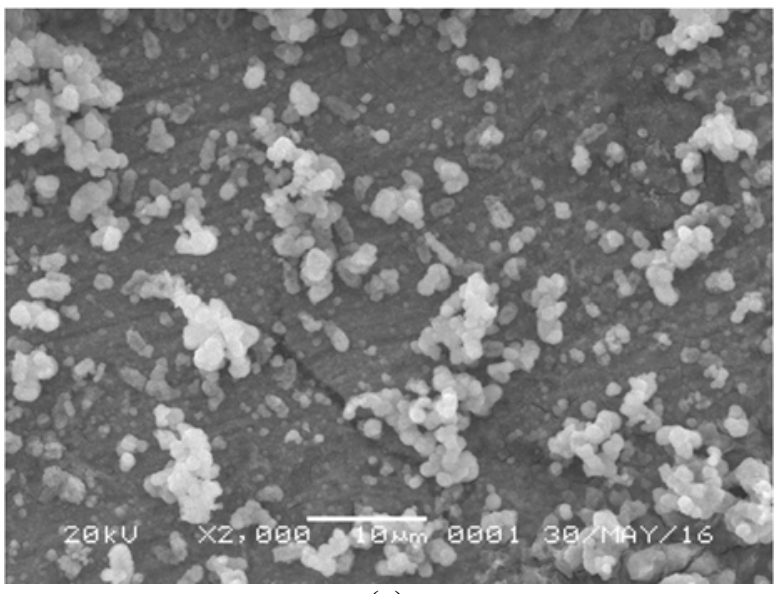

(a)

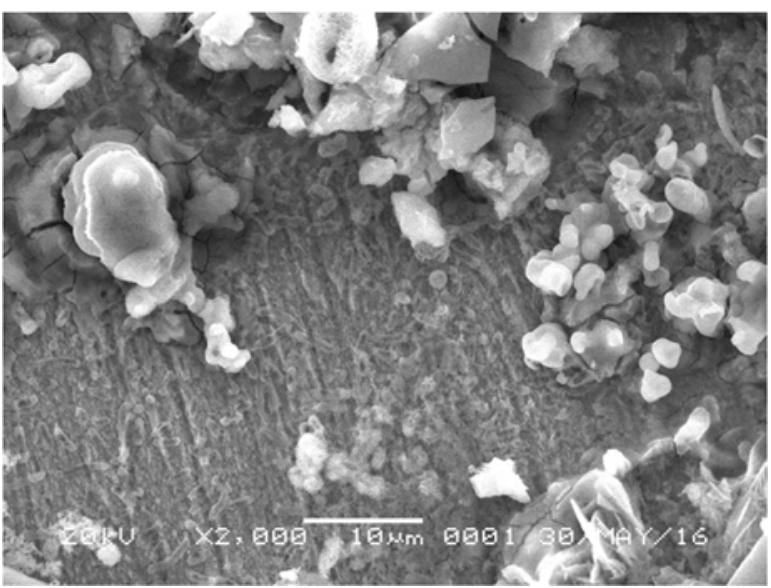

(b)

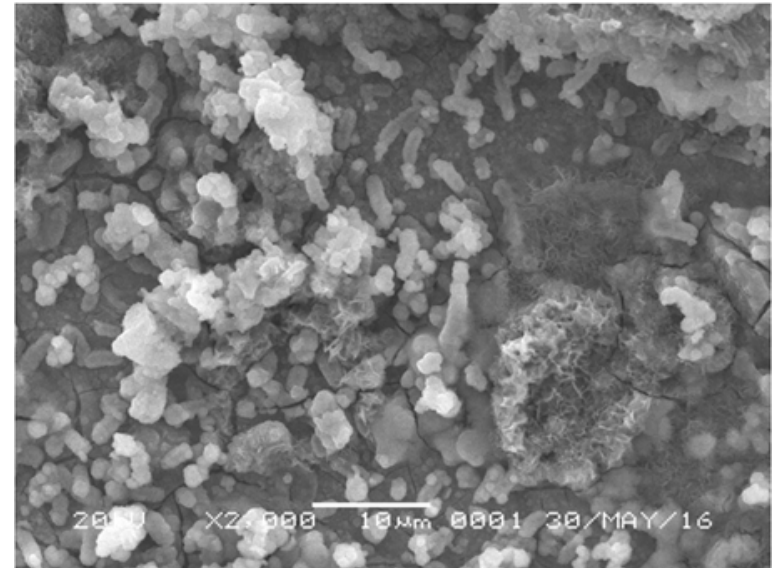

(c)

Figure 6. Biofilm morphology formed in immersion solutions at day 7 with initial pH: (a) 5, (b) 7, and (c) 9

Based on Figure 6, the biofilm growth on metal surface was not significantly influenced by the initial $\mathrm{pH}$ of immersion medium after seven day of incubation. This was supported by the results of the colonies number, which is shown in Figure 6a.

Figure 7 indicates that for day 19, the metal damage was occurred due to the activity of Serratia marcescens, which was in the form of pitting corrosion. Pitting corrosion might occur due to the potential difference on the metal surfaces. The biofilms, which was formed by Serratia marcescens, may form localized corrosion cells on the metal surface. The biofilm can inhibit oxygen diffusion to the metal surface, which may cause a potential difference on the metal surface. The metal under the biofilm may be oxidized, while the uncoated metal by biofilm may introduce the oxygen reduction reaction. Furthermore, Serratia marcescens could secrete acidic metabolites, which may be more concentrated on the metal surface and cause a severe corrosion.

The composition of the biofilm was analyzed using FTIR spectroscopy. The results are shown in Figure 8. This figure indicates that the functional groups that was detected at various $\mathrm{pH}$ was similar. It is shown in Figure 8 that the biofilm contains fatty acids (C-H bond) at $2910 \mathrm{~cm}^{-1}$; protein $(\mathrm{N}-\mathrm{H}$ bond) at 1600 $\mathrm{cm}^{-1}$; water and alcohol (O-H bond) at $3400 \mathrm{~cm}^{-1} ; \mathrm{N}=\mathrm{O}$ bond at $1380 \mathrm{~cm}^{-1}$; C-O bond at $1000 \mathrm{~cm}^{-1}$; and S-S bond, indicating polysulfide, at $480 \mathrm{~cm}^{-1}$.

The corrosion rate, which is a reaction kinetics parameter, can be determined by calculating the weight loss of carbon steel after being incubated in the medium. The immersion solution contained Serratia marcescens, and the result was compared with the solution without Serratia marcescens as a control variable. 


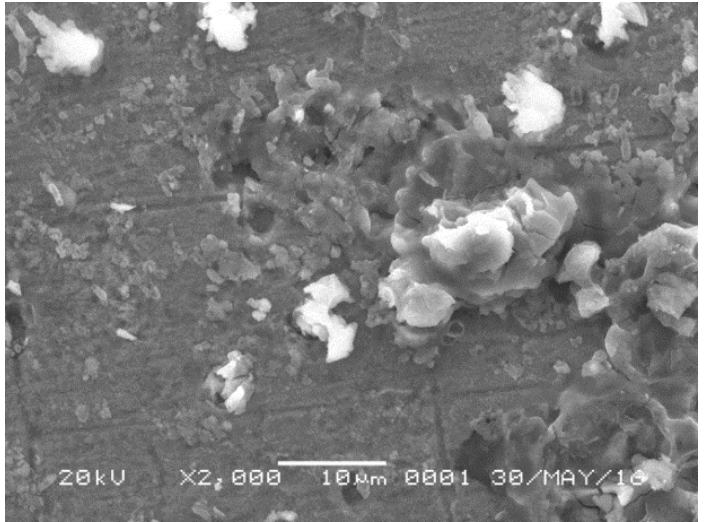

(a)

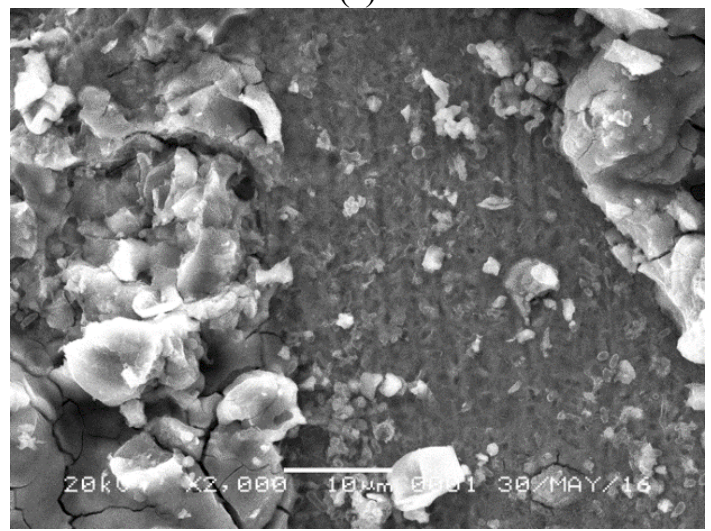

(b)

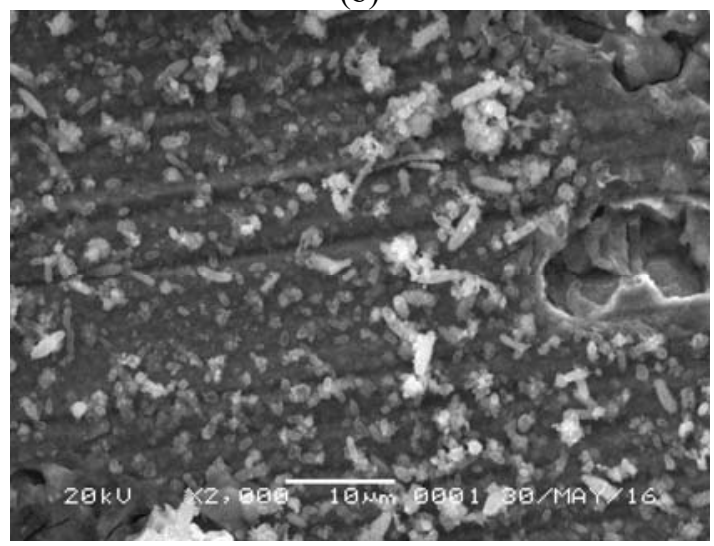

(c)

Figure 7. Biofilm morphology formed in immersion solutions at day 19 with initial pH: (a) 5, (b) 7, and (c)

9

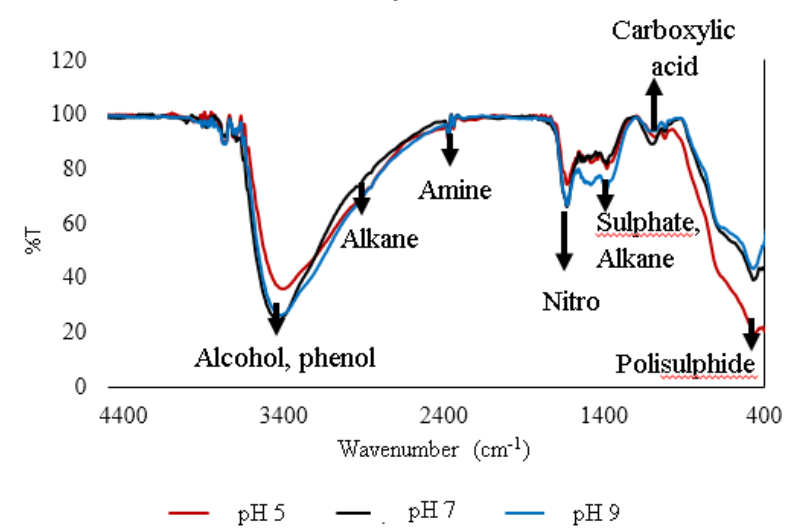

Figure 8. FTIR spectrum of Serratia marcescens biofilm at various $\mathrm{pH}$.
In general, the pattern of weight loss in the variation samples were greater than those in the control samples. The metal weight loss at various $\mathrm{pH}$ is shown in Table 3.

Figure 9 illustrates the corrosion rate of each $\mathrm{pH}$ variation. The average corrosion rate at $\mathrm{pH}$ variations of 5, 7, and 9 were $2.5309 \mathrm{~g} / \mathrm{m}^{2}$.day; $2.2844 \mathrm{~g} / \mathrm{m}^{2}$.day; and $2.9756 \mathrm{~g} / \mathrm{m}^{2}$.day, respectively. The average corrosion rate had the smallest number on the $\mathrm{pH} 7$. This may be due to the growth of Serratia marcescens at $\mathrm{pH} 5$ and 9 that is greater than at $\mathrm{pH}$ 7. The tendency of corrosion rate was similar to the corrosion rate profile of carbon steel corrosion by SRB (Ismail et al., 2014).

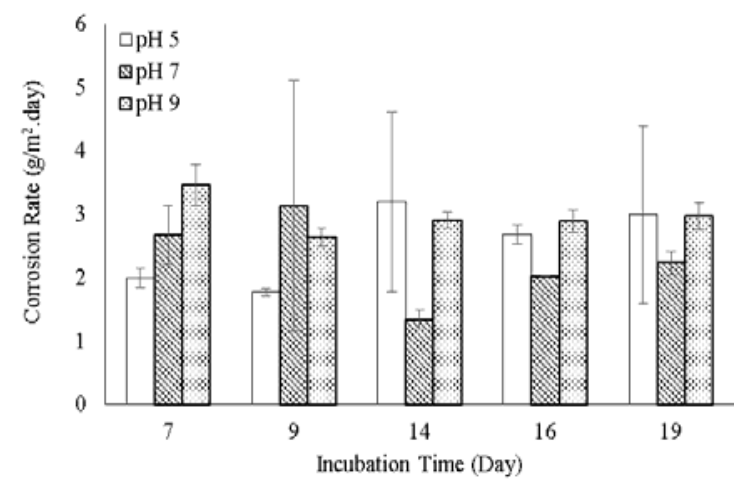

(a)

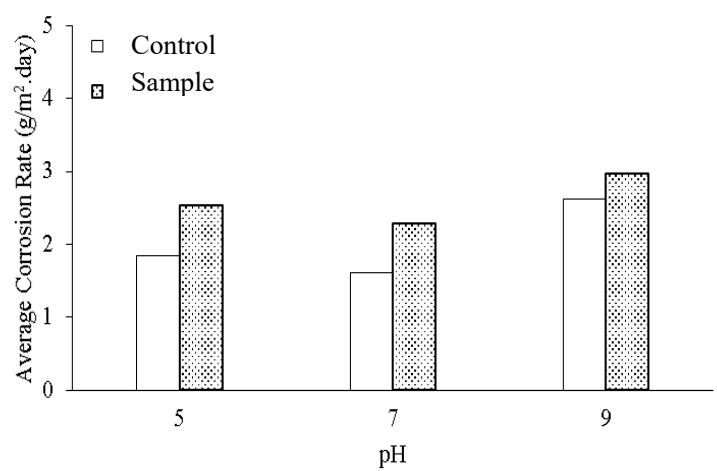

Figure 9. (a) The corrosion rate and (b) average corrosion rate at various temperatures

Hejazi and Falkiner (1997) stated that Serratia marcescens grow optimally at $\mathrm{pH}$ 6.5-7.5. In the experiment, Serratia marcescens showed rapid growth in the solution with initial pH 5 and 9. The immersion solution with $\mathrm{pH} 5$ was prepared using citrate buffer, while the solution with $\mathrm{pH} 7$ and 9 were prepared using phosphate buffer. These buffer compounds can be used as nutrition source by Serratia marcescens, and thus their rapid growth can be occurred. During their growth, acidic metabolites, such as organic acid and carbon dioxide, may be produced, which could increase the rate of corrosion. Therefore, the corrosion rate in the variation specimen had greater value than the control specimen.

The $\mathrm{pH}$ is essential as the alkaline environment assists in microbial activity by fasten the production of metabolic product, such as acidic metabolites (Ismail et 
al., 2014). Cao et al. (2009) stated that the dissolution rate of metabolites is faster at higher level of $\mathrm{pH}$. Because of that, the metabolic product would be accumulated under the biofilm, moreover, increased the corrosion rate of carbon steel. Thus, the corrosion rate of carbon steel in higher $\mathrm{pH}$ was higher as compared to lower $\mathrm{pH}$.

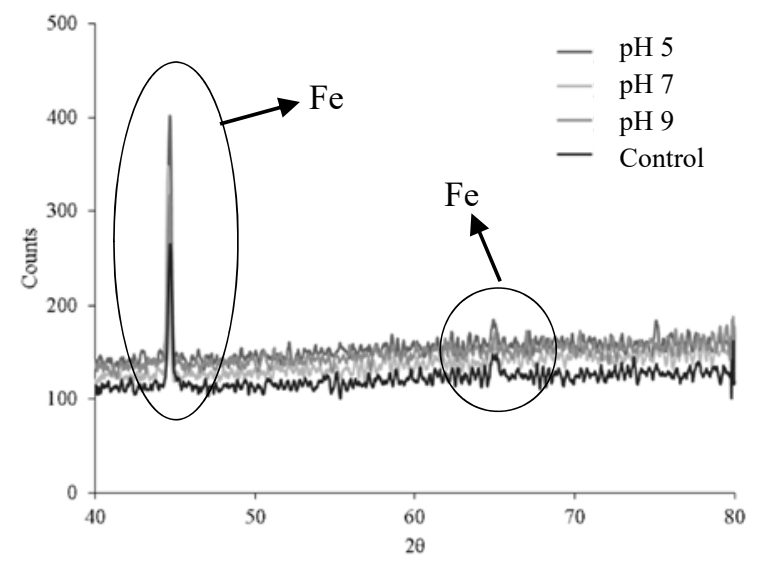

Figure 10. XRD spectra of carbon steel sample at various incubation $\mathrm{pH}$

All of the data shown previously could be used to explain the corrosion mechanisms. The mechanism of corrosion that might occur during the experiment can be seen in Figure 11.

Corrosion mechanism begins with carbon steel corrosion by the dissolved oxygen, which is the main compound that causes corrosion, and the chloride ions $\left(\mathrm{Cl}^{-}\right)$. In $\mathrm{pH} 5$, the dissolved oxygen is reduced into water $\left(\mathrm{H}_{2} \mathrm{O}\right)$, whereas in $\mathrm{pH} 7$ and 9 , it is reduced into hydroxide ions $\left(\mathrm{OH}^{-}\right)$. The reduction of oxygen is a cathodic reaction. The oxidation reaction or anodic reaction is the oxidation of iron into ferrous ions $\left(\mathrm{Fe}^{2+}\right)$. Chloride ions $\left(\mathrm{Cl}^{-}\right)$has the ability to destroy the passive layer on carbon steel surface, which can trigger the corrosion.

The corrosion products was analyzed using $\mathrm{XRD}$, and the results are shown in Figure 10. Carbon steel specimen before incubation, as the control, shows three peaks, which reflect the iron $(\mathrm{Fe})$ peak. The XRD spectra of metal samples, for all variation of $\mathrm{pH}$, indicates the similar peak as the control metal peak. This result illustrates that the corrosion product was not detected. This might occur because the product may be in dissolved form and interact with biofilm compound that may be lost during XRD sample preparation.

The rapid growth of Serratia marcescens may cause a significant decrease in the dissolved oxygen content in the environment. Thus, an anaerobic condition may be created in the system during the incubation period. In the anaerobic condition, Serratia marcescens can produce acidic metabolites, which are the result of metabolism of amino acids from the LuriaBertani. These amino acids can be further metabolized into pyruvic acid and acetic acid. The metabolites will be concentrated around the biofilm layer and some will dissolve into the immersion solution. The concentrated metabolites around the biofilm will cause the conditions around the metal to be more acidic. Hence, the corrosion rate of carbon steel increases.

Based on FTIR and XRD data, corrosion products might be in the form of $\mathrm{Fe}(\mathrm{OH})_{2}, \mathrm{FeS}$, and $\mathrm{FeCO}_{3} . \mathrm{Fe}(\mathrm{OH})_{2}$ is the result of the reaction between the ferrous ions $\left(\mathrm{Fe}^{2+}\right)$ and hydroxide ions $\left(\mathrm{OH}^{-}\right)$.

Table 3. Specimens weight loss at various $\mathrm{pH}$ during incubation.

\begin{tabular}{ccccccc}
\hline Incubation $\mathrm{pH}$ & \multicolumn{7}{c}{5} \\
\hline Day & 7 & 9 & 14 & 16 & 19 & Average \\
Weight loss variation (\%) & 0.2079 & 0.2487 & 0.7024 & 0.7248 & 0.8603 & 0.5488 \\
Weight loss control (\%) & 0.1256 & 0.2401 & 0.4797 & 0.3741 & 0.8843 & 0.4208 \\
\hline Incubation pH & & \multicolumn{2}{c}{7} & 7 & & \\
\hline Day & 7 & 9 & 14 & 16 & 19 & Average \\
Weight loss variation (\%) & 0.2700 & 0.3947 & 0.3059 & 0.5388 & 0.6759 & 0.4371 \\
Weight loss control (\%) & 0.1339 & 0.2669 & 0.1687 & 0.4283 & 0.6788 & 0.3353 \\
\hline Incubation pH & & & & 9 & & \\
\hline Day & 7 & 9 & 14 & 16 & 19 & Average \\
Weight loss variation (\%) & 0.3693 & 0.3852 & 0.6272 & 0.6819 & 0.8808 & 0.5889 \\
Weight loss control (\%) & 0.2364 & 0.3239 & 0.5771 & 0.6971 & 0.8490 & 0.5367 \\
\hline
\end{tabular}

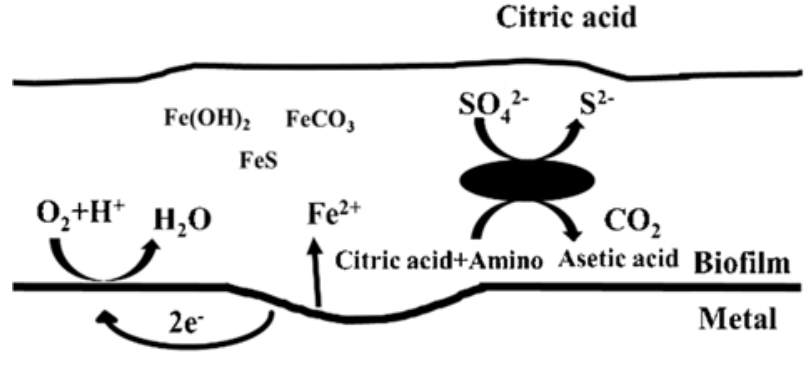

(a)

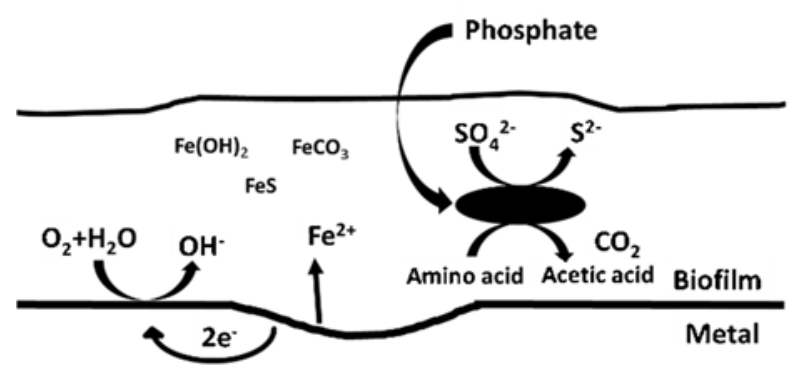

(b)

Figure 11. Corrosion mechanism of carbon steel by Serratia marcescens in the immersion solution with: (a) $\mathrm{pH}$; ; (b) $\mathrm{pH} 7$ and $\mathrm{pH} 9$ 
Ferrous ion is introduced from oxidation reaction, while hydroxide ion from the reduction of oxygen and water. The other estimated corrosion product is $\mathrm{FeS}$ since the immersion solution had black color and rotten smell at the end of incubation period. FeS is the reaction product between the ferrous ions $\left(\mathrm{Fe}^{2+}\right)$ and sulphide ions $\left(\mathrm{S}^{2-}\right)$. Sulphide ions are derived from the sulphate metabolism through the sulfur metabolism in Serratia marcescens. In the sulphur metabolism, the sulphite reducing enzymes could use adsorbed hydrogen $\left(\mathrm{H}^{\circ}\right)$ to reduce the sulfate. The corrosion product could also be $\mathrm{FeCO}_{3}$, which can be produced from carbonate ions $\left(\mathrm{CO}_{3}{ }^{2-}\right)$ that is introduced from carbon dioxide. Regarding the XRD results, corrosion products might be in soluble form because $\mathrm{Fe}^{2+}$ ion can bind to the carboxyl group of biofilm extracellular polymeric compounds (Little and Lee, 2007).

\section{CONCLUSIONS}

The difference in the incubation $\mathrm{pH}$ provides a significant influence on the colonies number growing in biofilm. The biofilm growth rate was found to be greater in $\mathrm{pH} 9$ than in $\mathrm{pH} 5$ and 7. The Serratia marcescens growth in the solution was inversely proportional to the biofilm growth. The $\mathrm{pH}$ did not have a significant influence on the biofilm composition. The biofilm consists of alcohol $(\mathrm{O}-\mathrm{H})$, fatty acids $(\mathrm{C}-\mathrm{H})$, protein $(\mathrm{N}-\mathrm{H})$, nitrous oxide $(\mathrm{N}=\mathrm{O})$, carbonyl $(\mathrm{C}-\mathrm{O})$, and polysulfide (S-S) bond. The corrosion rate of carbon steel by Serratia marcescens was influenced by the $\mathrm{pH}$. The $\mathrm{pH}$ variation of 5 and 9 was obtained to increase the corrosion rate. The average corrosion rate at $\mathrm{pH}$ variations of 5,7 , and 9 were $2.5309 \mathrm{~g} / \mathrm{m}^{2}$.day; $2.2844 \mathrm{~g} / \mathrm{m}^{2}$.day; and $2.9756 \mathrm{~g} / \mathrm{m}^{2}$.day, respectively. However, the corrosion products were not detected by $\mathrm{XRD}$ analysis.

\section{REFERENCES}

American Standard Testing and Material, ASTM G181, (1999), Standard Practice for Preparing, Cleaning, and Evaluation Corrosion Test Specimens.

American Standard Testing and Material, ASTM G3172, (2004), Standard Practice for Laboratory Incubation Corrosion Testing of Metals.

Brennenstuhl, A.M. and Doherty, P.E., (1990), The Economic Impact of Microbiologically Influenced Corrosion at Ontario Hydro's Nuclear Plants, Microbiologically Influenced Corrosion and Biodeterioration, University of Tennessee, United States of America.

Cao, J., Zhang, G., Mao, Z., Fang, Z., and Yang, C., (2009), Precipitation of Valuable Metals from Bioleaching Solution by Biogenic Sulfides, Mineral Engineering, 22, pp. 289-295.

Fang, Herbert H.P., Xu, L.C., Chan, K.Y., (2002), Effects of Toxic Metals and Chemicals on Biofilm and
Biocorrosion, Journal of Water Research, 36, pp. 47094716.

Flemming, H.C., (1996), Biofouling and Microbiologically Influenced Corrosion (MIC) an Economical and Technical Overview, Microbial Deterioration of Materials, Springer, London.

Hejazi, A. and Falkiner, F.R., (1997), Review Article: Serratia marcescens, Journal Medical Microbiology, 46, pp. 903-912.

Ismail, M., Noor, N.Md., Yahaya, N., Abdullah, A., Rasol, R.Md., Rashid, A.S.A., (2014), Effect of pH and Temperature on Corrosion of Steel Subject to Sulphatereducing Bacteria, Journal of Environmental Science and Technology, 7, pp. 209-217.

Costerton, J.W., Lewandowski, Z., Caldwell, D.E., Korber, D.R., and Lappin-Scott, H.M., (1995) Microbial Biofilms, Annual Review Microbiology, 49, pp. 711-745.

Jack, R., Ringelberg, D., and White, D., (1992), Differential Corrosion Rates of Carbon Steel by Combinations of Bacillus sp., Desulfovibrio gigas Established by Phospholipid Analysis of Electrode Biofilm, Corrosion Science, 27, pp. 174-181.

Javaherdashti, R., (2008), Microbiologically Influenced Corrosion: An Engineering Insight, Springer, London, pp.29-45.

Little, B.J. and Lee, J.S., (2007) Microbiologically Influenced Corrosion, John Wiley \& Sons, Inc., Hoboken, New Jersey, pp. 1-36.

Muthukumar, N., Maruthamuthu, S., and Palaniswamy, N., (2006), Water-soluble Inhibitor on Microbiologically Influenced Corrosion in Diesel Pipeline, Journal of Colloids and Surfaces, 53, pp. 260270.

Pillay, C. and Lin, J., (2014), The Impact of Additional Nitrates in Mild Steel Corrosion in a Seawater/Sediment System, Journal of Corrosion Science, 80, pp. 416-426.

Xiaoxia, S., (2007), Biofilm Formation and Its Induced Biocorrosion of Metals in Seawater, $P h D$ Thesis, National University of Singapore, Singapore.

Xu, D. and Gu, T., (2014), Carbon Source Starvation Triggered More Aggressive Corrosion Against Carbon Steel by the Desulfovibrio vulgaris Biofilm, Journal of International Biodeterioration and Biodegradation, 91, pp. 209-217.

Yuan, S., Liang, B., Zhao, Y., and Pehkonen, S.O., (2013), Surface Chemistry and Corrosion Behaviour of 304 Stainless Steel in Simulated Seawater Containing Inorganic Sulphide and Sulphate-reducing Bacteria, Journal of Corrosion Science, 74, pp.353-366. 